ISSN: 2224-0616

Int. J. Agril. Res. Innov. \& Tech. 8 (1): 79-84, J une, 2018

Available online at http:/ / www.ijarit.webs.com

\title{
TRANS-BOUNDARY WATER CONFLICTS BETWEEN BANGLADESH AND INDIA: WATER GOVERNANCE PRACTICE FOR CONFLICT RESOLUTION
}

\author{
A. Parven ${ }^{*}$ and M.S. Hasan ${ }^{2}$ \\ Received 30 April 2018, Revised 20 June 2018, Accepted 26 June 2018, Published online 30 June 2018
}

\begin{abstract}
Bangladesh and India Sharing fifty-four trans-boundary rivers water that flows from India to Bangladesh. Bangladesh is mostly dependent on India for their water and has no control over the water shed management policy of the rivers. Being a smaller, weaker military and economy than India, Bangladesh cannot influence the watershed management policies and face floods and water scarcity, reducing yield production and fish productivity, an ecological imbalance in estuarine areas, saline water intrusion in the southwestern part of Bangladesh and reduced navigation. Water governance is the combination of the political, social, economic and administrative system, which manage the water resources and provide services in the different level of society. Based on the water governance definition the researchers find out the different stakeholder in the management of water governance and the lack of practices of the theoretical concept of water governance and try to indicate the possibilities of the better solutions (Conflict or cooperation) of this trans-boundary water conflicts between both countries. The paper also compared the present negotiation process with different kinds of modes of wicked problem in water resource management. The study recommends few suggestions to minimize the conflict over the utilization of trans-boundary water resources management for example, a hydro-community like EU water framework Directive that is based on the soft power of peer review rather than a penalizing measure.
\end{abstract}

Keywords: Bangladesh, India, Trans-Boundary River, Water Governance, Wicked Problem, Conflicts, Hydro-Community

\footnotetext{
${ }^{1}$ Assistant Professor, Dept. of Fisheries and Marine Science, Noakhali Science \& Technology University, Noakhali, Bangladesh

${ }^{2}$ Expert in Marine Pollution Management and Shipping Management, Anglo-Eastern Group, Hong Kong, Singapore.

*Corresponding author's email: afshana.parven@gmail.com (A. Parven)
}

\section{Introduction}

Bangladesh and India are South Asian countries. Bangladesh shared $4094 \mathrm{~km}$ of land borders with India on three sides and the fourth side is opened with Bay of Bengal (Dutta, 2010). There are various issues between Bangladesh and India needs to resolve. Sharing water of fifty-four transboundary rivers (Sood and Mathukumalli, 2011) that flows from India to Bangladesh is one of the major issues to resolve. Bangladesh is mostly dependent on India for their water and has no control over the water shed management policy of the rivers. Being a smaller, weaker military and economy than India, Bangladesh cannot influence the watershed management policies (Sood and Mathukumalli, 2011) and face floods and water scarcity, reducing yield production and fish productivity, an ecological imbalance in estuarine areas, saline water intrusion in the southwestern part of Bangladesh and reduced navigation. Being a smaller country, Bangladesh has less opportunity to bargain over the water issues with India. As a powerful actor, India tends to gain hegemony over other actors especially on the lower riparian country Bangladesh that is also found in the river Scheldt case (Buuren and Warner, 2009). In both countries the conflict resolution mechanism is mainly is state dependent and other relevant stakeholder remains neglected. Access to water, lack of transparency and accountability and water rights was always overlooked by India, and the conditions remain so (Mayers et al., 2009) According to Rogers and Hall (2003), water governance is the combination of the political, social, economic and administrative system, which manages the water resources and provide services in the different level of society. Whereas Moench et al. (2003) thought that water governance is a decision-making process, which shows the path to the decision maker that how a decision will be made, who will make the decisions under the particular circumstances. 
Water governance definition suggests embracing different formal and informal institutions in the management of water. According to the description, the researchers find the different stakeholder in the management of water governance and the lack of practices of the theoretical concept of water governance and try to indicate the possibilities of the better solutions (Conflict or cooperation) of this trans-boundary water conflicts between both countries. Therefore, the paper compared the present negotiation process with different kinds of modes of wicked problem in water resource management (Lach et al., 2005). This paper will also try to indicate the track followed and still following in the river Teesta regime.

\section{History of this trans-boundary water conflicts}

The GBM (Ganges-Brahmaputra-Meghna) is one of the most extensive freshwater river flows in the world. The Ganges originated from Himalaya, and before entering into Bangladesh, it flows about $1500 \mathrm{~km}$ (Chowdhury and Ward, 2007). The Brahmaputra originated from Tibet plateau and crossed northeastern part of India to open in Bangladesh. These two rivers come together inside Bangladesh and Ganges named as the Padma. The Padma flows $150 \mathrm{~km}$ to join with the river Meghna and drain in the Bay of Bengal. Bangladesh, Nepal, India, China, and Bhutan are considered the users of this vast GBM basin (Tradewell and Ali, 2009).

Sharing trans-boundary Rivers causing sociopolitical issues since the birth of India and Bangladesh (Formerly East Pakistan). IndiaBangladesh trans-boundary water conflict started to the early 1970s (Islam, 2012). Hundreds of millions of people are living around the bank of the shared rivers, dependents on their livelihoods (Social and economic) and cultural lives (Rahman et al., 2000). A conflict arises due to water sharing and controlling of demand and supplies of water in both up and downstream (Uprety, 2012). The primary conflicts between Bangladesh and India started on the building of Farraka dam in 1961 on the Ganges river to maintain the navigability of Calcutta port, near the border of Bangladesh which was operated in 1975 (Tanzeema and Faisal, 2001). Water flow in the Bangladesh part considerably low since the barrage started its operation and Bangladesh faces a serious drought problems and saltwater intrusion problem in the Southwestern of Bangladesh (Rahman et al., 2000). As a downstream riparian country freshwater availability of Bangladesh totally dependent on the Upstream India and faced 50\% decrease the flow amount of water in the dry season and since the commissioning of the barrage in 1975 (Tradewell and Ali, 2009). Similarly, India planned to divert water from the river Brahmaputra to the Farakka. By considering the adverse impact of the plan to the riparian country, Bangladesh objected and the negotiation continued without any result (Kristian et al., 2013). The former Indian Prime Minister Indira Gandhi was unwilling to operate the Farakka barrage without the consent from Bangladesh but situation changed after the assassination of the Former Bangladesh President Sheikh Mujibur Rahman (Kristian et al., 2013). Later, India withdrawal the bilateral negotiations about the water sharing with the Former President Ziaur Rahman in 1976. India started to use the water unilaterally and when Ziaur Rahman approached India for discussion but there was no response from other party. So, the issue internationalized in the UN General assembly in 1976. Besides this, the conflict rages over the Teesta water sharing (Islam, 2011). Due to the India's internal requirement they have unilaterally divert policy and withdraw water from those transboundary/International rivers (Ramaswamy, 1997). Without any agreement with Bangladesh, India has started to build several dams from many trans-boundary rivers such as, Teesta, Gumti, Khowai, Dharla, Dudhkumar, Monuetc and also blocked many rivers such as Muhri, Chagalnaiya, Fulchuri, Kachu and many others which flow from Tripura (India) to Bangladesh (Islam, 2012). Bangladeshi water expert said that India has heavily modified the flow of 48 out of 54 rivers and that is heavily affecting the economy of Bangladesh (Kristian et al., 2013). Recently, Indian high court approved a controversial river diversion project in which India can link Brahmaputra and Ganges River by a canal to store the excess water of Brahmaputra to the Ganges. Dhaka is also concern about this controversial river linking project. Moreover, the recent Tipaimukh dam construction in the river Barak River of the Indian state of Manipur, Mizoram and Assam added a new fume to this long trans-boundary water conflict issues in both countries (Kristian et al., 2013). Dam construction over the Barak River has adverse effect on the flow of Surma and Kushiara River on the northeastern region of Bangladesh.

\section{Materials and Methods}

Secondary data source used for this paper to analyze the trans-boundary water conflicts between Bangladesh and India. Moreover, different papers, journals, websites, used during the whole work process and content of this paper based on the summarized view of those sources. Discussion and conclusion is completely the writer's personal understanding based on qualitative analysis of the existing literature and the analysis available on the issues. The transboundary water issues of Bangladesh divided into 
three sections- water scarcity, susceptibility to flooding and water quality.

\section{Analysis of the problem}

During the analysis of the problem various power conflicts, economic incentives over water conflicts for a successful negotiation, impact of water crisis on the environment will focus.

\section{The Teesta regime}

The Teesta is the fourth major trans-boundary rivers of Bangladesh and India after the Ganges, Brahmaputra and Meghna (Uprety and Salman, 2011). An agreement signed between Bangladesh and India to share the Teesta water as 36\% for Bangladesh and 39\% for India. The remaining $25 \%$ would leave unallocated for the natural flow of Teesta River in 1983. Two countries decided to have complete scientific studies to share the water. Joint Teesta commission established to fulfill this purpose. Due to Teesta Barrage and several hydroelectric dam constructions, the river heavily silted. The river has changed its courses in many places of lower stream Bangladesh and every year engulfing thousands of hectares land. The dream of irrigating to increase the agriculture production becomes failure in both countries (Uprety and Salman, 2011). Expert revealed that due to the water scarcity, the Teesta barrage will lose its usefulness and there is a possibility of death of the river. Both countries involved the chairperson of the irrigation department to find out the way for the sharing arrangements into a formal documentation. However, the new bilateral treaty discussed to sign on 2012 to allocate the equal portion of water in both countries but the West Bengal Chief Minister Ms. Mamata Banarjee denied the treaty with an excuse that the state government did not have enough discussion with the West Bengal Government regarding these issues. She also mentioned that if this treaty has signed then it has adverse irrigation impact on their part. As water is a state asset of India and State Government has a coalition with the Mamata's Trinomul Party, State Government did not proceed without further consultation with West Bengal Government (Prasai and Mandakini, 2013). Again, failure to sign Teesta agreement, the bilateral discussion about the transit facilities for India through Bangladesh slowed down and the fate of the sharing of other trans-boundary river hanged on (Prasai and Mandakini, 2013). Despite having of several meeting with Joint River Commission, J oint Expert Committee, J oint Technical Group, the bilateral discussion between Bangladesh and India now become intractable. The discussion was technical in nature with a very small room for discussion of social and ecological issues or other stakeholders. Public participation and civil society engagement was very narrow in this whole process of negotiation. After considering the whole scenario of Teesta river regime, the water governance in this region falls in track 1 type of water governance (Dore, 2007). Track 1 type of water governance involves government in a formal and informal way with bureaucracy in an intra and interstate forum (Dore, 2007). The decision making process is more official in this type of water governance. The dominant logic behind this track is accepting the implicit rational dominancy (Dore, 2007); and focused on the selfinterested behavior that is completely visible in the trans-boundary water issue management in Bangladesh and India.

This type of water governance has mostly followed the mode 1 (Lach et al., 2005) where the governance design is mostly in technical where engineers and hydrologist are more critical stakeholder who treats water as a natural resource and built water systems and overlook all related uncertainty. In this Teesta regime, the same things happen at the beginning of the barrage building where the two-state gives concentration to those stakeholders and avoided related risk and uncertainty.

With the year, passing the water management situation in this barrage was in danger and new stakeholders showed up their face in the negotiation process, so the problem becomes a wicked problem. Different stakeholders bringing further information are inevitable. It is not possible to solve by a single organization and the one solution for one generation may have a problem for others. In this case, when the twostate faced the challenge then the commission asked to study the issue further, create new knowledge and find further solutions. Therefore, we find a shifting of track 1 type of governance to track 2 governance and the water management mode 2 (Lach et al., 2005). It is not possible to say that water management mode has completely shifted from mode 1 to mode 2 but we can say that the management system is changing, though the power is still on the government hand. In this Teesta regime more stakeholders forcefully joined as a stakeholder but they were not indeed invited to cooperate or allowed to say.

In this Teesta regime, we find "soft power' is exercised where problems are framing and reframing and had an active attempt to influence the actors in the decision-making process. In the case of weak power utilization, it has discussed that why the other actors will coexist, goes along, or not resist, or aligned with the interest of another party, though it is ethically not correct. There are so many reasons behind this such as in the real world, there are winners and losers in the trans-boundary water management and negotiation process. The interest of one party intertwined with the interest of another party (Zeitoun et al., 2011). There is a myth that India 
helps Awami League (AL) to be in power, which is similar to soft power using in the trans-boundary negotiation.

In a trans-boundary water interaction in an integrative exercise, one actor may be framed the issue in a way that other parties accept the portrayal without any question. This case is very similar to India-Bangladesh trans-boundary water issue problem where Bangladesh accept India's negotiation strategy without questioning. It has believed that the official consensus between Bangladesh and India focused on the politically feasible pragmatic way to manage the water conflicts in which it is also overlooked that how much compliance is achieved. It is temporary and stabilizes the cause of conflict, but it is better than ignoring the issues that are also describe by Zeitoun et al. (2011). When the soft power used in a hegemonic trans-boundary water arrangement, then it is shown that soft power can lunch or turned off the options for the other riparian actors for example more powerful side India can shape up the outcome of the discussion. It indicates by Zeitoun et al. (2011) that unbalanced hegemonic bargain is more easily preserve than altered.

In the case of Teesta regime, the hegemony has its clearance in a more integrative way to manage the trans-boundary arrangement. To achieve a "carrot" in a privileged way both countries extended their hand is, of course, a common. For example, Bangladesh agreed to provide the corridor to India for their connection with the mainland, and land-locked northeastern state for their transportation and India proposed to share Teesta water equally (Islam, 2012). However, the treaty has not signed, this type of agreement verbally done between the Government of Bangladesh and India. There are many examples of such regional co-operations around the world where the incentives often not directly relate to the water-related issues, for example, Turkey and Syria Euphrates river water sharing (Zeitoun et al., 2011).

\section{Water politics in the trans-boundary water sharing}

The trans-boundary water issue is a severe sociopolitical issue in Indo-Bangla region (Formerly East Pakistan) (Tradewell and Ali, 2009).

There are always a considerable uncertainty and less information about the impact of water management and dam building in the Tipaimukh area. However, it becomes a political challenge both in Bangladesh and in Northeast of India. In India, it showed a state-society conflict (Yumnam, 2014). In Bangladesh, Civil society comes forward against the Tipaimukh dam construction, for example, they set up a committee named as a Tipaimukh Dam Resistance Committee. In Bangladesh Sylhet area will be profoundly affected if the dam is built so, local people organize a committee to protest the dam namely Unnayan Sangram Committee. Not only that the political parties also made a coalition of all parties including the CPB (Communist Party of Bangladesh). In the national state, Bangladesh Nationalist Party (BNP) the then opposition party of Bangladesh, highly criticize the decision of India's dam-building efforts (Kristian et al., 2013).

It has always been revealed that when Awami League (AL) into the power of Bangladesh they still follow the conciliatory policy with India. It has also proved during the Ganges treaty in 1996. Therefore, Awami League (AL) Government answered the critics of the opposition party that no dam will construct until AL is in Government, which also expressed the closeness of $\mathrm{AL}$ with India. However, it has proved that the both Government of two countries lost their credibility (Kristian et al., 2013).

Teesta river negotiation hanged on because of the Indian internal politics and struggle of the state center power. They showed up their face and entered into the negotiation process. Though the agreement was negotiated by the Government of India and Bangladesh, pulling out immediately prior the signing in 2011 bilateral meeting of the two Government (Kristian et al., 2013), just because of the chief minister of the Indian state of West Bengal.

Recently, in a public meeting, the former West Bengal Chief Minister Buddhadeb Vottacharya said that the discussion about the Teesta water and eccentricity corridor could be discussed with Bangladesh in another rational way. $\mathrm{He}$ also mentioned that Indian Bengal province want good relations with all neighboring countries but not at the cost of the friendship of Bangladesh (eprothomalo, p.17).

Concerned citizens from Bangladesh shared their observation about the deficiency in clearness and answerability to the counterparts in Northeast India and West Bengal in dam building, water diversion project as well as the water sharing agreements. India also showed less interest in water sharing and failure to share information and not progress with the further consultation with the stakeholders in Bangladesh. IndiaBangladesh water diplomacy relationship failed because of the mistrust, unproductive cooperation. Nowadays, civil society comes forward as an essential stakeholder in both countries with the new alliances in their anti-dam movements. Governments in both countries are facing a new challenge for the raising of new stakeholder. However, this new arising 
stakeholder giving fresh opportunities for the opposition politics (Kristian et al., 2013).

\section{From Conflict to Cooperation}

In 2011 when the Prime Minister Manmohan Sing visited Dhaka, highlighted the improvement of bilateral cooperation on the management of shared river (Kristian et al., 2013). The diplomats and the leaders in both countries feel the same. Though it is still stated dependent, two nations agreed to promote trans-boundary water management, hydropower development including the ecosystem protection. In this case, India tried to show cleaner image by inviting delegates from parliaments, opposition leaders of Bangladesh and the J ournalists to the Tipaimukh dam. India also agreed to share the environmental assessment report and formulated terms of references (TOR) in 2012. India also offered Bangladesh joint venture hydroelectric project in North-East India to increase the power production in both countries by sharing both cost and benefits.

Awareness is rising in both countries to have an integrated water resource management approaches in focus with the necessity of multipurpose and basin wise cooperation mechanisms with different national and international stakeholders (Kristian et al., 2013). Experts of the participating countries in India's northeast hydropower grid will foster the cooperation among them.

Moreover, an International organization such as Global Water Partnership introduces the Integrated Water Resources Management (IWRM) in Bangladesh and India to set up the "3e's" means the efficiency of the water resources, equity in allocation in different social and economic group and environmental sustainability. The present water resource management is the more top-down approach, technical based and management are unsustainable (Kristian et al., 2013). India water Partnership (IWP) works with different stakeholders including policy makers, donors and representative from industry to work on the resolutions of interstate trans-boundary water sharing and organize a water dialogue. On the other hand, Bangladesh Water Partnership (BWP) works on flood management, adaptation to climate change, trans-boundary water cooperation and promoting best practices for knowledge sharing. IUCN is trying to set a knowledge hub for integrated ecosystem management of common water regimes. IUCN also showed an active interest in the dialogue in water management issues between Bangladesh and India (Kristian et al., 2013). It is not always correct that relatively weaker party do not get benefit from the use of soft power e.g. Egypt-
Sudan Nile treaty which was mentioned as an example by Zeitoun et al. (2011).

\section{Conclusions and Recommendations}

India shared the water from the trans-boundary river according to their will and took the advantages to be the upper riparian country. In existing water sharing policy, there is a lack of integrated water sharing management. India disobeys the international river law and shows no attitude of concession to Bangladesh (Islam, 2012). Moreover, the political party in Bangladesh is another factor to expose the policies unsuccessfully. The existing policies are not working well because of the lack of regional cooperation and conventional wisdom in water sharing issues with these countries. Through this study, it has found that there are so many reasons behind this lack of consensus about the transboundary issues between Bangladesh and India such as lack of political and national consensus, selective foreign policy, poor water governance, water scarcity in both countries. It suggests that if there is no future consensus about the sharing of trans-boundary waters, there may be a possible inter and intrastate conflicts in both and between countries and disease outcome will increase due to the lack of fresh water (Islam, 2012). The area, population, and size are relatively smaller than other trans-boundary river area. By studying all the situations and negotiation process, the following recommendation is acknowledged.

\section{Recommendation for Bangladesh and India}

- Increase the access to the information: This is not only recommended for Teesta basin but also recommended for other shared river basins. This access to data is not only for the state sharing but also increase the public accessibility into the data.

- During the dialogues and negotiation, consider the entire river basin as a unit of analysis considering that basin is more important in ecological and economical than a fixed use of it.

- Paradigm is shifting from track two process to track-3 for a new starting of negotiations.

- Discuss the interchange of tradable and sharable benefits in the water sharing a negotiable table: It has already seen in the negotiation of the Teesta river regime.

- Civil Society Organization (CSO) should come forward with advocacy and intermediary roles, but trust building is more important to engage in this issues. CSO should more link with the grassroots people and help to mobilize them for coalition about the shared interest.

- Donor organization should come forward for capacity building and provide support in the negotiation process as non-state actor. 
It is also recommending that Bangladesh and other South Asian countries may build up a hydro-community like EU water framework Directive that is based on the soft power of peer review rather than a penalizing measure. It is to notifying that the inter-state water conflict in this state in the adverse situation never understood and addressed in the same way that European Union faces in their water conflict issues. Therefore, the trans-disciplinary water conflict is unique for an individual country.

\section{References}

Buuren, M.W. van and Warner, J. 2009. Multistakeholder Learning and Fighting on the River Scheldt. Int. Negotiation. 14: 417-439.

Chowdhury, M.R. and Ward, M.N. 2007. Seasonal flooding in Bangladesh - variability and predictability. Hydrol. Process. 21: 335347.

Dore, J. 2007. Mekong Region Water-Related MSPs-Unfulfilled Potential. In: Jeroen Warner (ed.), Multi-Stakeholder Platforms for Integrated Water Management, Ashgate Publishing Ltd., England. pp. 205-234.

Dutta, P. 2010. India Bangladesh relations: Issues, problems and recent developments. IPCS special report, Institute of Peace and Conflict, India. $4 \mathrm{p}$.

http:// www.eprothomalo.com/index.php?opt=vi ew\&page $=1 \&$ date $=2014-01-30$. p. 17

Islam, M.S. 2011. Water scarcity and conflict: A Bangladesh perspective, The Daily Star Monthly Magazine Forum. 5 (6): 19.

Islam, S. 2012. Bangladesh-India Water Sharing Disputes: Possible Policy Responses. J . Bangladesh Stud. 14 (1): 38-49.

Kristian, H., Katherine, E., Jason, M., Silje, H., J oyeeta, B., Line, B., Farzana, J., Hari, B.J . and Asshild, K. 2013. Water Scarcity in Bangladesh. Transboundary Rivers, Conflict and Cooperation, PRIO Report, 1. Oslo: PRIO. pp. 1-135.

Lach, D., Rayner, S. and Ingram, H. 2005. Taming the waters: strategies to domesticate the wicked problems of water resource management, Int. J. Water. 3 (1): 1-17.

Mayers, J., Batchelor, C., Bond, I., Hope, R. A., Morrison, E. and Wheeler, B. 2009. Water ecosystem services and poverty under climate change: Key issues and research priorities. International Institute for Environment and Development, London, UK. Natural Resource Issues No. 17. pp. 163.

Moench, M., Dixit, A., Janakarajan, M., Rathore, S. and Mudrakartha, S. 2003. The fluid mosaic, water governance in the context of variability, uncertainty and change. Nepal. Papers No. 7, Global Water Partnership, Technical Committee, Stockholm, Sweden. pp. 1-63.

Prasai, S. and Mandakini, D.S. 2013. Political Economy Analysis of the Teesta River Basin. New Delhi: The Asia Foundation. pp. 1-38.

Rahman, M.M., Hassan, M., Islam, M.S. and Shamsad, S.Z.K.M. 2000. Environmental impact assessment on water quality deterioration caused by the decreased Ganges outflow and saline water intrusion in south-western Bangladesh. Environ. Geol. 40 (1-2): 31-40.

Ramaswamy, R.I. 1997. The Indo-Bangladesh Ganga Waters Dispute. South Asian Survey. 4 (1): 129-144.

Rogers, P. and Hall, A.W. 2003. Effective Water Governance. Global Water Partnership Technical Committee (TEC) Background Papers 7. pp. 7-43.

Sood, A. and Mathukumalli, B.K.P. 2011. Managing international river basins: reviewing India- Bangladesh trans-boundary water issues. Int. J. River Basin Manage. 9 (1): 43-52.

Tanzeema, S. and Faisal, I.M. 2001. Sharing the Ganges: a critical analysis of the water sharing treaties. Water Policy. 3: 13-28.

Tradewell, J. and Ali, S.A. 2009. Contributing Factors in the Ongoing Water Conflict Between Bangladesh and India. Tufts University Aquapedia Beta. pp. 1-14.

Uprety, K. 2012. Transboundary Water Governance: Lessons for South Asia. GWF Discussion Paper. Canberra, Australia: Global Water Forum, 2012. http://www. globalwaterforum.org/ 2012/09/03/ transbo undary-water-governance-lessons-forsouthasia.

Uprety, K. and Salman, S.M. 2011. Legal aspects of sharing and management of transboundary waters in South Asia: preventing conflicts and promoting cooperation. Hydrol. Sci. J . 56 (4): 641-661.

Yumnam, J. 2014. Transboundary water conflicts and Tipaimukh dam. Water for the people network. Retrieved from https:/ / mygoldenbengal.wordpress.com/ 201 4/12/ 14/transboundary-waters-tussle-andtipaimukh-dam.

Zeitoun, M., Mirumachi, N. and Warner, J. 2011. Transboundary water interaction II: The influence of 'soft' power. Int. Environ. Agree. Politics Law Econ. 11(2): 159-178. 